\title{
Isenções fiscais justificadas por necessidades especiais ou despesas de saúde: instrumentos para a promoção de justiça ou conquista de privilégios?
}

\author{
Raquel ALMEIDA-MARQUES(1)
}

\author{
${ }^{(1)}$ Universidade São Paulo - USP, São Paulo, SP, Brasil.
}

Recebido: 28 jan 2019 Aceito: 10 fev 2019

Autor de correspondência: raquelmarques@usp.br

Conflito de interesses: Os autores declaram não haver nenhum interesse profissional ou pessoal que possa gerar conflito de interesses em relação a este manuscrito.

\section{Resumo}

No ordenamento jurídico brasileiro há leis e projetos de leis que buscam, de diversas formas, promover melhores condições de vida e acesso a tratamento para pessoas com problemas crônicos e debilitantes de saúde. Em alguns casos, as normas visam poupar, através de renúncias fiscais, recursos financeiros dos doentes ou familiares que seriam devidos ao erário ou a empresas que administram concessões públicas. As soluções trazidas por estas leis ou projetos de lei que propõem renúncias fiscais têm como justificativa o fato que, em muitos casos, estes pacientes não encontram solução, de maneira gratuita e universal, na assistência oferecida pelo Estado. Assim, através do não pagamento de impostos ou tarifas, o legislador espera favorecer o orçamento familiar destes doentes para que encontrem, através de serviços privados, os recursos necessários ao tratamento e reabilitação. Sem dúvida, no âmbito pessoal, tais medidas fazem diferença na qualidade de vida da maior parte dos beneficiados. Contudo, enquanto política pública, é preciso refletir sobre a eficácia das iniciativas considerando os recursos alocados e o bem-estar do conjunto da população. A Receita Federal define gasto tributário como "gastos indiretos do governo realizados por intermédio do sistema tributário, visando a atender objetivos econômicos e sociais e constituem-se em uma exceção ao sistema tributário de referência, reduzindo a arrecadação potencial e, consequentemente, aumentando a disponibilidade econômica do contribuinte". Recursos que o Estado deixa de arrecadar em decorrência de isenções são também recursos que deixam de ser aplicados em prol da coletividade. Neste contexto, é razoável questionar se estas soluções são meios para a promoção da justiça social em saúde, ou instrumentos para o agravamento de desigualdades econômicas e sociais. Trata-se de uma discussão sobre necessidade, eficiência e equidade em saúde. Para esta análise foram selecionadas três iniciativas legislativas: Lei 8.989/1995, sobre a isenção do Imposto sobre Produtos Industrializados - IPI, na aquisição de automóveis para utilização no transporte autônomo de passageiros, bem como por pessoas portadoras de deficiência física; Lei 7.713/1998, que dispõe sobre a legislação do imposto de renda; e Projeto de Lei do Senado 199/2016, que dispõe sobre a isenção da tarifa de pedágio nas vias federais pelos veículos que transportem pessoas com doença grave ou degenerativa. A Lei 8.989/1995, ao conceder descontos na aquisição de veículos para pessoas portadoras de deficiências, 
moléstias graves e estende este benefício aos seus cuidadores, não encaminha o verdadeiro problema: as dificuldades de locomoção das pessoas com deficiência ou fragilizadas. Ao oferecer como uma solução estatal para a falta de transporte público adequado o desconto para a aquisição de veículos novos, assume-se como premissa um recorte de classe importante. Em um país onde a maior parte da população conta com recursos escassos para a sobrevivência, trata-se de uma solução excludente. Embora, certamente, tal desconto seja relevante para o orçamento de famílias com condições para adquirir um veículo, a medida não oferece solução a todas as pessoas portadoras de deficiências ou moléstias graves. A Lei 7.713/1998, que dispõe sobre imposto de renda, isenta o pagamento deste imposto os portadores de alguns tipos de patologias. $\mathrm{Na}$ ausência de teto para esta isenção, e considerando que o imposto de renda tributa as pessoas com remunerações acima de um determinado patamar, ou seja, as pessoas com maior renda, esta isenção desonera o orçamento de pessoas com renda mais alta, sem compor compensação proporcional às pessoas isentas do pagamento deste imposto ou que estão em faixas menores de tributação. Com isso, quem tem mais imposto a pagar é muito mais beneficiado do que pessoas com baixa renda e que, provavelmente, possuem mais necessidade de recursos. O Projeto de Lei do Senado 199/2016, ainda em tramitação, visou amenizar as despesas de deslocamento das pessoas que precisam buscar tratamento de saúde em cidades vizinhas, através da isenção do pagamento de pedágios rodoviários. Esta medida deixa de encaminhar o problema sistêmico relativo ao transporte de pacientes entre cidades, conectando baixa, média e alta complexidade do sistema de saúde. Assim como a Lei 8.989/1995, não oferece solução equivalente aos cidadãos que não possuem condições de ter um veículo próprio. Estes três exemplos são pontos de partida para o questionamento da melhor aplicação dos recursos públicos. Sem desconsiderar as necessidades especiais de alguns grupos em decorrência de sua condição de saúde, ou de membros de suas famílias, a discussão que se coloca é qual o caminho para a promoção da equidade, evitando a ampliação das desigualdades. O primeiro ponto de destaque nos três casos é que as propostas exigem condição de renda elevada para que o cidadão seja elegível ao benefício. O segundo ponto é a falta de critério para sua concessão. Usando como exemplo a Lei 7.713/1998, a isenção de imposto de renda é total, independentemente da faixa de renda do beneficiado ou custo de tratamento. E o terceiro ponto, e certamente o mais relevante, é que nenhum dos projetos visa medidas compensatórias aos cidadãos com demandas semelhantes, mas que não preenchem os requisitos de renda necessários ao alcance dos benefícios apresentados. Estas iniciativas, embora aparentemente benéficas, pouco contribuem para a justiça social e a promoção da equidade em saúde. Suas soluções oferecem alternativas às pessoas que já contam com mais recursos, mas não resolvem os problemas que identificam de maneira universal.

Descritores: Saúde Pública; Sistema Único de Saúde; Economia da Saúde. 